\title{
Preparation of Out-of-School Learning Environment based on Science, Technology, Engineering, and Mathematics Education and Investigating its Effects"
}

\author{
Esra Bozkurt Altan ${ }^{1 *}$, İrem Üçüncüoğlu², Nurhan Öztürk \\ ${ }^{1}$ Department of Science and Mathematics Education, College of Education, Sinop University, Sinop, Turkey, ${ }^{2}$ Department of Science Education, \\ Institute of Science, Sinop University, Sinop, Turkey \\ *Corresponding author: esrabozkurt@sinop.edu.tr \\ \# $\quad$ This research was carried out within the scope of CEAUM-1901-17-16 project supported by Sinop University Scientific Research Projects.
}

\section{ABSTRACT}

This research aimed at preparing an out-of-school Science, Technology, Engineering, and Mathematics (STEM) education program for secondary school students and investigating the effects of the program on students' interest in STEM fields. As part of this investigation, this study sought the students' awareness of a career in these fields as well as their comments on the process and the contribution of the process to the $21^{\text {st }}$ century skills. The research was conducted with a mixed methods research design. The participants of the research consisted of 24 secondary school students. The data were collected through STEM career interest survey, STEM perception test, participants' STEM diary, observation, and field notes. The study's out-of-school STEM education program lasted 8 days. This study's findings include students had an increased awareness and perception of building a career in the fields of STEM. It was confirmed that students had fun during the activities, and during the entire process, they made positive comments. Implications from this research highlight how this type of activity may improve the $21^{\text {st }}$ century skills of the students.

KEY WORDS: career awareness; out-of-school learning; perceptions; Science, Technology, Engineering, and Mathematics education; $21^{\text {st }}$ century skills

\section{INTRODUCTION}

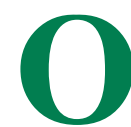
ut-of-school learning environments can offer students exciting and motivating learning opportunities that formal environments cannot. As a result, in an effort to spread Science, Technology, Engineering, and Mathematics (STEM) education that is based on an integration of disciplines, national education reforms in many countries have shifted STEM education to out-of-school learning environments (Feder and Jolly, 2017). This shift has been supported by a body of international literature that highlights those practices based on an integration of STEM disciplines in informal environments such as STEM centers, science centers, museums, botanic gardens, or by means of planned camp programs (National Research Council, 2012; 2015; STEM Education Coalition, 2016).

STEM education is based on the integrated teaching of STEM disciplines within the context of real-life problems and in coherence with the works of real-life professionals. In this sense, it is essential for students to encounter problems similar to real-life or real-world contexts. This includes experiencing problems similar to those that professionals working in the STEM fields and requires the utilization of more than one STEM discipline (if possible, all of them). Models based on the integration of disciplines are addressed by English (2016) as multidisciplinary, interdisciplinary, and transdisciplinary. The multidisciplinary approach requires linking together, when necessary, the content of subjects learned at different times in different courses and may be related to one another. The interdisciplinary method is centered on the learning domain of a course. The problem case presented to help the student acquire the learning outcomes of this learning domain is planned to include the knowledge and skills in the other disciplines. On the other hand, the transdisciplinary approach is not centered on the learning domain of a specific course; rather, the focus is on reallife problems. The students concentrate on solving the problem. The problem requires the integration of a number of disciplines. It is believed that when these models are considered, it may be possible to focus on real-life problems that require the setting of STEM disciplines collectively to work in out-of-school learning environments. Hence, since disciplinary courses such as science or mathematics require teaching the content of the learning domains of a specific discipline, it is most appropriate to base these courses mostly on the interdisciplinary model to put STEM education into practice. Therefore, out-of-school learning environments gain importance in allowing students to confront real-life problems in which STEM disciplines are involved in an integrated manner. 
In that sense, this research aimed at preparing an out-of-school STEM education program for secondary school students and investigating the effects of the program on students' interest in STEM fields and their awareness of career in these fields, to include student comments on the process and the contribution of the process to the $21^{\text {st }}$ century skills.

\section{LITERATURE REVIEW}

\section{Out-of-School Programs and the Importance of the Program for STEM Education}

Out-of-school learning may be performed in environments such as museums, nature trips, botanic gardens, as well as in camps with planned content or science schools. In this research, an out-of-school learning environment has been designed with a content planned in line with the goals of STEM education, promising to give certificates to the participants when the learning outcomes were achieved.

Stevens et al. (2005) have reported that children in Grades 1-12 spend only $18.5 \%$ of their time at school. The learning environments in which the students are involved in the remaining period could inevitably enhance their learning outcomes. Hence, various researches have argued the positive effects of out-of-school learning environments. Uitto et al. (2006) have found out that out-of-school learning environments promoted students' interest in biology. In a study performed with university students having education in STEM fields, Dabney et al. (2012) concluded that the interest students have in developing their career in STEM fields boosted by not only their gender and their interest in science and mathematics but also their attendance to scientific activities out of school. Grolnick et al. (2007) highlighted that science programs outside of the school influence the motivation, self-sufficiency, and school performance of students. Numerous researchers have underlined that students develop a positive perception of science in science camps, improve their beliefs in the nature of science, and raise their opinions of scientists (e.g., Kırıkkaya et al., 2011; Cavaş, 2011; Leblebicioğlu et al., 2011; Metin and Leblebicioğlu, 2011). The National Research Council (NRC) (2009) states that out-of-school applications of content make positive contributions to the academic success of students and their development of a scientific career.

The NRC (2015) points out to the fact that to popularize this education method, it is essential to plan the period children spend outside the school in line with STEM education. As such, research indicates the importance of structuring outof-school learning environments in parallel with STEM education (Afterschool Alliance, 2013; Baran et al., 2016; Bicer et al., 2015; Dubetz and Wilson, 2013; Sullivan, 2008; Şahin et al., 2014). Baran et al. (2016) implemented an out-ofschool STEM education program for $6^{\text {th }}$ grade students. The researchers investigated student's perceptions about the STEM activities implemented in the program. In this research, it was determined that the students thought this program contributed to their skills in cognitive, design, engineering, and work with computers. In a research conducted with experts who provided support to carry out out-of-school STEM programs, Afterschool Alliance (2013) reported that both the supporters and the experts were in consensus about the idea that out-ofschool programs enhanced the interest of youth in STEM fields, raised awareness of careers in these fields, boosted the curiosity for STEM fields, and helped raise the importance of STEM disciplines for society. Sullivan (2008) planned a summer camp of robotic courses for secondary school students and found that the camp improved the systematic thinking skills of the students. Şahin et al. (2014) suggested that afterschool STEM activities were potential contributors to the development of the $21^{\text {st }}$ century skills of students as well as offering the students a cooperative learning environment and encouraging them to question things. Bicer et al. (2015) concluded that summer camps involving project-based learning helped enhance the conceptual knowledge of secondary school students in the fields of mathematics and science.

\section{Career Awareness and Perceptions in STEM Field}

The importance to be given to STEM fields was manifested in the USA, the country of origin of this approach, in the motivation provided to the students for developing a career, particularly in STEM fields of study (NAE and NRC, 2009; NGGS, 2013; NRC, 2012; PCAST, 2010). This was the consequence of the findings that American students have a lower preference for STEM fields when compared to other fields (PCAST, 2010). Similarly seeing that there was a tendency in Australia toward the fields of science, while engineering and mathematics are not preferred as much, Australia saw a need to popularize STEM education to raise students' awareness of these fields (Aydeniz and Bilican, 2017). Likewise, attention was drawn in Europe to the need for giving greater weight to STEM education so that the younger generation not only showed more interest in STEM fields but also that this education has become a requirement (Aydeniz and Bilican, 2017). Kızılay (2018) investigated STEM fields in Turkey. The researcher pointed out that employment and career rates for STEM areas are quite low. However, it was emphasized in a report issued by the Turkish Industry and Business Association (2014) that a qualified workforce should be trained to contribute to the global economy in these fields. Furthermore, statistical data from the Turkish Higher Education Board (YÖK) indicated that only $13 \%$ of the students who were admitted to universities in Turkey in 2014-2015 preferred STEM fields of study.

Individuals should decide on their area of profession in line with their interests, expectations, and competencies. However, knowing about the professions first could be considered as a prerequisite for this. Therefore, it is important to design suitable environments during and after secondary education for individuals to be curious about and inquire into professions and business world (Muro and Kottman, 1995). Many countries commonly and mainly focus on the need to have a well-educated workforce, stronger in terms of quality if not quantity, in the STEM fields. Therefore, it is essential to improve students' awareness of the nature of each of the STEM 
fields, create environments where they will get to know and show interest in these fields, and give them an awareness of career development in these fields.

Christensen and Knezek (2017) inquired into how secondary school students perceive STEM and what their attitude toward STEM career objectives was and found male students in secondary schools to be more interested in building a career in STEM fields. Within the framework of the project named Girls in Engineering, Mathematics, and Science, Dubetz and Wilson (2013) investigated that the effects of the applied activities on the interest female students in secondary schools show for STEM. It was concluded that attending to STEM activities and having close contact with women working in STEM fields of study have helped female students show increased interest toward STEM fields. Wyss et al. (2011) identified that students show more interest in having a career in STEM fields of study after talking to professionals working in those fields.

\section{$21^{\text {st }}$ Century Skills and STEM Education}

One of the most important objectives of STEM education is having individuals equipped with the must-have skills of this century (NAE and NRC, 2009, 2014; NAGB, 2014; NRC, 2012). The must-have skills for individuals in the $21^{\text {st }}$ century have been identified by various organizations (AACU, 2007; ISTE, 2007; OECD, 2017; P21, 2013). The common $21^{\text {st }}$ century skills mentioned are as follows: Researching questioning, critical thinking, problem-solving, creativity, innovation, initiative, communication, information and media literacy, technology literacy, ethical reasoning, and lifelong learning. Various organizations also draw attention to the importance of skill development (Lisbon European Council, 2000; OECD, 2017). STEM education's contribution to the development of the $21^{\text {st }}$ century skills makes this approach important. A number of studies have argued how STEM education takes thinking skills to higher levels and contributes to the development of skills including problem-solving, decision-making, innovative and rational thinking, technology literacy, and making discoveries (Baran et al., 2016; Fllis and Fouts, 2001; Sahin et al., 2014; Smith and Karr-Kidwell, 2000).

\section{METHODOLOGY}

\section{Model of Research}

The research design of this study was the concurrent nested design, which is a mixed method research design. Creswell (2012) defines concurrent nested design as the model in which researchers collect both qualitative and quantitative data in one research and analyze the data sets separately and where such data answer different questions in the research. The quantitative part of the research has a single group pre-test/ post-test experimental design. Single group experimental design was a practical solution for reaching a group of participants to understand the cause-effect relation of the problem (Shaughnessy et al., 2006). The qualitative part of the research, on the other hand, was based on case study design. Marshall and Rossman (2006) emphasized that a case study is used in evaluating a program or in researches with an in-depth or detailed focus on an event.

\section{Participants}

The participants of the research consisted of 24 secondary school students (11 boys and 13 girls) in the $6^{\text {th }}, 7^{\text {th }}$, and $8^{\text {th }}$ grades. Students, all of whom were attending public schools, made individual applications to the program for the STEM project planned as an out-of-school learning environment. To give an equal chance to all potential participants, the selection was made with the simple random sampling method from among the voluntary applications.

Nineteen of the participants had an academic success average of 95 of 100 and above, four between 90 and 95, and one in the 80-85 range. All of the participants $(n=24)$ had working fathers and 16 had working mothers as well. 19 of the participants were from middle socioeconomic status considering that at least one parent had a consistent job, a college degree and had an average Turkish middle-income monthly salary of 5250 Turkish liras (€), which is equivalent to approximately 1000 USD. Five of the students were from lower socioeconomic status as at least one parent had a job, but none of the parents had a college degree and had an average monthly salary of 3150 Turkish liras (€) or \$600 USD.

\section{Data Collection Tools}

Quantitative and qualitative data collection tools were used in the research. The data collection tools in use were as follows:

\section{STEM Career Interest Survey}

The "STEM Career Interest Survey" was developed by Kier, Blanchard, Osborne, and Albert (2013) and adapted to the Turkish context by Ünlü et al. (2016). This survey instrument was used to identify how effective the project activities were on increasing the interest of participants in having a career in the STEM fields. The STEM Career Interest Survey consists of 40 items with a 5-point Likert scale. The survey has four subdimensions: STEM with each subdimension having 10 items. Examples of survey subdimension items: Science - $I$ am able to get a good grade in my science class. If I do well in science classes, it will help me in my future career. I am interested in careers that use science; Mathematics - I like my mathematics class. I would feel comfortable talking to people who work in mathematics careers. I have a role model in a mathematics career; Technology - I am able to do well in activities that involve technology. I am able to learn new technologies. I plan to use technology in my future career; and Engineering - I am interested in careers that involve engineering. I like activities that involve engineering. I have a role model in an engineering career. The survey is based on Bandura's social cognitive learning theory. The total score to be earned for each subdimension varies between 10 and 50 .

\section{STEM perception test}

The 'STEM Perception Test' was developed by Christensen and Knezek (1998) and adapted to Turkish by Gülhan and Şahin (2016). This survey instrument was used to assess the 
effect of out-of-school STEM activities on how the participants perceive the STEM fields. The test has subdimensions of STEM, and STEM career perception. There are five adjectives and antonymous adjectives for each of the subdimensions in the test. There are seven alternatives between the two opposite ends. The test includes the following adjectives for each subdimension (STEM and STEM career): Fascinatingmundane, appealing-unappealing, exciting-unexciting, means nothing-means a lot, and boring-interesting. The students were asked to choose the one they felt closest to from among these alternatives on the scale. The test was evaluated by scoring seven for positive adjectives and one for negative ones. Therefore, the total score to be earned in each subdimension has a maximum of 35 . The higher the score, the more positive the perception of STEM the student.

\section{Participants' STEM diary}

Participants kept STEM diaries in which they wrote down, at the end of each day, their reflections of the daily activities performed in STEM learning environments (such as how interesting the activities were for them and in what ways they feel to have improved as a result). Diary papers were designed by the researchers but customized for students, on which students were asked to provide written accounts about their feelings and opinions for each activity. Participants' STEM Diaries were used for collecting data to analyze how the activities in the process contributed to the $21^{\text {st }}$ century skills.

\section{Observation of researchers and field notes}

Researchers made observations and kept field notes during the activities to find out which skills of the students (problemsolving, decision-making, etc.) were brought out by the activities and to supervise how the students work throughout this process.

\section{Context of Research}

Five different STEM-centered activities were developed in this research. The development of these modules was on problem-based learning or the engineering design process. In STEM activities featuring problem-based learning, students are presented with a problem case, suitable for their context or real life, having more than one solution, and compatible with their background, which promotes cooperative learning involving the integration of at least two STEM disciplines. While looking for solutions to the problem, students are expected to learn knowledge and skills in the disciplines integrated into the problem (Duch et al., 2001; Hung, 2009).

In STEM activities based on the engineering design process, students are given an engineering problem for which a solution is to be found using the engineering design process (Brunsell, 2012; NAE and NRC, 2009; NRC, 2012). Engineering problems, which involve criteria and constraints, are suitable for finding more than one solution and require the integration of STEM disciplines. Criteria can be defined as the qualities of the product or system to be designed that must be present to be successful and constraints as the possible obstacles to overcome in making a successful product or system design
(Brunsell, 2012). For example, in a refrigerator design, the criteria could be energy efficiency and having a large volume. Obstacles such as cost, time, and time limits on developing the best design could be constraints. Students are asked to identify and clearly state the criteria and constraints of the problem first. Then, students do research and mini designs to produce solutions to the problem. They need to do this research and mini designs to acquire the knowledge and skills required for the solution to be developed. In the next stage, students are asked to choose the most suitable one from among possible solutions, make a prototype, and test it. The testing stage may be followed by design improvements, if necessary. This process is based on the design process of real engineering (NAE and NRC, 2009).

Five activities were prepared. The activity designs were sent to three different experts other than the researchers, including science and mathematics instructors working in the field of STEM education, then revised, and finalized according to their comments. All of the activities were carried out in groups consisting of four and five students each. To give a clearer idea of the content of the implemented practices, the content of some of the activities designed for the project are as follows.

\section{Traffic lights design for the visually impaired}

An activity module named "traffic lights design for the visually impaired" was developed to draw students' attention to the difficulties faced in daily life by visually impaired people in their surroundings. In this module, students were asked to develop a design that would help a visually impaired person cross the street by unassisted in a traffic zone. Planned within the framework of the engineering design process, this module was for the students to develop a solution for the problem case using Arduino software. The activity was for the integration of engineering, science, and mathematics disciplines. The activity took 12 periods (each period for all activities consisted of $40 \mathrm{~min}$ ).

\section{Water for the living things}

This activity was prepared to draw attention to the water and food requirements of street animals in the hot summer months. In this activity required the students to design a water vessel for street animals with the following dimensions; this activity module required the students to design a water vessel for street animals with the following dimensions: Height $10-15 \mathrm{~cm}$, width $20-25 \mathrm{~cm}$, and volume 2.5 liters. Planned within the framework of the engineering design process, this module was aimed at the integration of mathematics, technology, science, and engineering. The activity took 12 periods.

\section{Birdhouse design}

Students were asked to design a birdhouse for protecting the migrating birds from dangers in their routes of migration. In this module, planned within the framework of engineering design process, students were asked to prepare their designs in consideration of bird characteristics (wingspan, mass, length, etc.), the periods when the birds were in the region, the location of the house, and the weather conditions and design a birdhouse 
with a limited budget (in this study, the budget was limited to 20 Turkish Lira) in which birds could be protected from the surrounding dangers and nestlings could grow without harm. The activity was for the integration of mathematics, science, and engineering disciplines. The activity took seven periods.

\section{Socioscientific subjects and digital narration - nuclear power plants}

In this activity planned for carrying out STEM applications with problem-based learning, students were presented the problem case related to the nuclear power plants in Sinop, Turkey, in a context that allows for the integration of STEM disciplines. The problem case was presented with tables and graphs containing mathematical data that will help approach the socioscientific subject from several dimensions. The problem provided for the integration of science, technology, and mathematics disciplines. Students were expected to collaborate in their group discussions, agree on a solution to the problem case using the digital narration tool of their choice, and justify their decision. The activity took 10 periods.

\section{Moving problem for transport companies - crane design}

In this activity, students were given a scenario in which transport companies had to move objects in multi-storey buildings without using an elevator inside the building. The students were asked to make a 1/20 model of the building's dimensions to be used for moving furniture to the fourth floor. Planned within the framework of the engineering design process, this module was for the students to develop a solution for the problem case using Arduino software. The activity was for the integration of engineering, science, and mathematics disciplines. The activity took 12 periods.

All of the activities were completed in 8 days, with no more than seven periods in any 1 day.

\section{Data Analysis}

Descriptive analysis and content analysis method was used in reflections the STEM Diaries written by students at the end of each day of activity. Common codes were established for similar answers based on the statements written in the diaries for each activity module. These codes were groped in two themes, namely: Positive opinion and negative opinion. Frequency (f) values were calculated for each code. Furthermore, a descriptive analysis was done for the findings written in the diaries in relation to the skills that were developed with the help of the activities. The data obtained from field notes were examined using descriptive analysis to identify the $21^{\text {st }}$ century skills used in each activity. Field notes taken during the activities by two different researchers for finding out which skills of the students were uncovered by the activities were compared and, following a discussion of these field notes, the consensus was reached on which activity develops which skill of the students. The quantitative data obtained in the research (data obtained by Participants' STEM Career Interest and STEM Perception Test) were compared with t-test for the correlated samples.

\section{FINDINGS}

The findings obtained for this purpose are presented to address the study's research questions.

\section{STEM Career Awareness}

The findings related to the development of students' career awareness in STEM fields of study were obtained using paired sample t-test to compare the career awareness measurements calculated before and after attending out-of-school STEM education program and the results are shown in Table 1.

The pre- and post-test measurements of the students in the project revealed a statistically significant difference in favor of the post-tests in the subdimensions of science $\left(\mathrm{t}_{23}=-2.23 ; \mathrm{p}<0.05\right)$, engineering $\left(\mathrm{t}_{23}=-2.78 ; \mathrm{p}<0.05\right)$, and mathematics $\left(\mathrm{t}_{23}=-2.58 ; \mathrm{p}<0.05\right)$. However, there was no significant difference in the technology subdimension $\left(_{\text {technology }}=-1.606 ; \mathrm{p}>0.05\right)$. The total score to be earned for each subdimension varies between 10 and 50 . When the pre-test measurements were viewed from that perspective, the highest pre-test measurements were found in the career awareness calculated in science $\left(X_{\text {science-pre }}=40.19\right)$ and technology $\left(X_{\text {technology-pre }}=40.08\right)$ disciplines. Furthermore, the pre-test measurements in engineering $\left(X_{\text {engineering-pre }}=37.42\right)$ and mathematics $\left(\mathrm{X}_{\text {mathematics-pre }}=38.46\right)$ disciplines were above the average. It could be concluded from the findings that STEM career awareness of the students had been positively affected.

\section{STEM Perception}

The development of students' perception of STEM fields of study was evaluated using paired sample t-test to compare the measurements calculated before and after attending an out-of-school STEM education program. The findings are presented in Table 2.

As seen in Table 2, the pre- and post-test data of the students in the project revealed statistically significant difference in the subdimensions of science $\left(\mathrm{t}_{24}=-2.791 ; \mathrm{p}<0.05\right)$, technology $\left(\mathrm{t}_{24}=-2.508 ; \mathrm{p}<0.05\right)$, engineering $\left(\mathrm{t}_{24}=-2.402\right.$; $\mathrm{p}<0.05)$, mathematics $\left(\mathrm{t}_{24}=-3.106 ; \mathrm{p}<0.05\right)$, and STEM $\left(\mathrm{t}_{24}=-2.37 ; \mathrm{p}<0.05\right)$. Students obtained the highest pre-test measurement in science $\left(X_{\text {science-pre }}=20.11\right)$, followed by similar measurements in the subdimensions of STEM career $\left(\mathrm{X}_{\text {STEM career-pre }}=20.11\right)$, technology $\left(\mathrm{X}_{\text {technology-pre }}=20.11\right)$, engineering $\left(X_{\text {engineering-pre }}=20.11\right)$, and mathematics $\left(X_{\text {mathematics- }}\right.$ pre $=20.11$ ). On the other hand, considering that the total scores to be earned in each of the subdimensions vary between 5 and 35 , it could be said that the pre-application STEM awareness of the students was at average levels.

Students' Assessment of Out-of-School STEM Education STEM Diaries include student's comments on STEM activities, developed as part of the research, and applied to the students, under two categories titled "positive" and "negative" opinions. 


\begin{tabular}{|c|c|c|c|c|c|c|}
\hline Subdimensions & Measurement & $\mathrm{n}$ & $X_{\text {mean }}$ & $S$ & $t$ & $p$ \\
\hline \multirow[t]{2}{*}{ Science } & Pre-test & 24 & 40.19 & 9.54 & -2.23 & $0.035^{*}$ \\
\hline & Post-test & 24 & 43.11 & 8.46 & & \\
\hline \multirow[t]{2}{*}{ Technology } & Pre-test & 24 & 40.08 & 10.72 & -1.606 & 0.121 \\
\hline & Post-test & 24 & 43.24 & 5.46 & & \\
\hline \multirow[t]{2}{*}{ Engineering } & Pre-test & 24 & 37.42 & 11.20 & -2.78 & $0.010^{*}$ \\
\hline & Post-test & 24 & 42.31 & 7.89 & & \\
\hline \multirow[t]{2}{*}{ Mathematics } & Pre-test & 24 & 38.46 & 10.15 & -2.58 & $0.016^{*}$ \\
\hline & Post-test & 24 & 42.27 & 5.98 & & \\
\hline
\end{tabular}

*The level $\mathrm{P}<0.05$ means statistically significant difference. STEM: Science, Technology, Engineering, and Mathematics

Table 2: Comparison of STEM perception pre- and post-test measurements using paired sample t-test and the results obtained

\begin{tabular}{|c|c|c|c|c|c|c|}
\hline Subdimensions & Measurement & $\mathbf{n}$ & $X_{\text {mean }}$ & $S$ & $t$ & p \\
\hline \multirow{2}{*}{ Science } & Pre-test & 24 & 20.11 & 6.04 & -2.79 & $0.010^{*}$ \\
\hline & Post-test & 24 & 23.19 & 3.26 & & \\
\hline \multirow[t]{2}{*}{ Technology } & Pre-test & 24 & 18.59 & 7.46 & -3.11 & 0.019 * \\
\hline & Post-test & 24 & 21.85 & 3.89 & & \\
\hline \multirow[t]{2}{*}{ Engineering } & Pre-test & 24 & 18.52 & 7.58 & -2.40 & $0.024 *$ \\
\hline & Post-test & 24 & 21.67 & 3.77 & & \\
\hline \multirow[t]{2}{*}{ Mathematics } & Pre-test & 24 & 18.04 & 7.46 & -2.51 & $0.005 *$ \\
\hline & Post-test & 24 & 21.22 & 3.89 & & \\
\hline \multirow[t]{2}{*}{ STEM career } & Pre-test & 24 & 18.93 & 7.91 & -2.37 & $0.025 *$ \\
\hline & Post-test & 24 & 22.41 & 3.00 & & \\
\hline
\end{tabular}

* The level $\mathrm{P}<0.05$ means statistically significant difference

Table 3: Findings obtained from student's diaries

\begin{tabular}{|c|c|c|c|}
\hline \multirow[t]{3}{*}{ Activities } & \multirow[t]{3}{*}{$\mathbf{n}$} & \multicolumn{2}{|c|}{ Participant's views } \\
\hline & & Positive & Negative \\
\hline & & f & f \\
\hline $\begin{array}{l}\text { Traffic lights design for the visually } \\
\text { impaired }\end{array}$ & 24 & 23 & 1 \\
\hline Designing water bowl for street animals & 24 & 24 & - \\
\hline Birdhouse design & 24 & 24 & - \\
\hline $\begin{array}{l}\text { Socioscientific subjects and digital } \\
\text { narration: Nuclear power plants }\end{array}$ & 24 & 23 & 1 \\
\hline $\begin{array}{l}\text { Moving problem for transport } \\
\text { companies - Crane design }\end{array}$ & 23 & 22 & 1 \\
\hline
\end{tabular}

Then, the issues to which the students want to draw attention in relation to each activity are presented in combination with examples of sample student opinions. Findings related to students' assessment of the activities are given in Table 3.

As seen in Table 3, students, in general, made positive comments on all STEM activities. Student's assessments of each of the activities were addressed separately to shape their assessment of the process. For that purpose, student's comments on each activity were addressed separately.

Twenty-three students made positive comments and one student made a negative comment on the activity titled traffic lights design for the visually impaired. The only student who made a negative comment on the activity justified the dislike for the activity by saying they "dislike coding." However, the same student mentioned having enjoyed the stage of designing the traffic lights and the stage of raising awareness of visual impairment where the problem case was defined. The student making the negative comment has written the following statement:

It was not enjoyable today since I do not like coding, but the stage of building traffic lights was fine ... However, the morning opinions and activities about the visually impaired were very nice.

Students who made positive comments justified their opinions by saying, of frequency, that it contributed to their learning coding ( $f=21)$, raised awareness of the life of the visually impaired $(f=19)$, was fun $(f=12)$, helped empathize with the visually impaired $(f=6)$, and offered them the experience of problem-solving $(f=4)$ and that coding is compatible with their area of interest $(f=1)$. Some of the statements students made for this activity in their diaries are as follows:

...During the day, we learned about the experiences of the visually impaired. We learned to code with Arduino and lit the LEDs. We learned about the difficulties experienced by the visually impaired. We tried to find solutions for the visually impaired. We empathized with the visually impaired people. We learned the basics of coding. 
Today was very enjoyable. There was a subject that I was interested in: Coding... When disabilities are in question, people generally talk about the problems of hearing impairment or walking disability. However, today, we found a solution to the problems of the visually impaired. Besides, we learned about a software called Arduino and how to write code...

For the activity titled Designing Water Bowl for Street Animals, all of the students reported positive opinions. When stating their opinions about this activity, students said, of frequency, that they used the design processes ( $f=17)$, it was fun $(f=16)$, it raised awareness of street animals $(f=12)$, they learned to code $(f=4)$, and they did teamwork $(f=2)$. Some of the statements students made for this activity in their diaries are as follows:

Today, we had a lot of fun again. We learned about the problems of street animals. Then, we tried to design a water bowl in the science laboratory, which turned out to be a total defeat. However, still, it was fine to work on designs...

I learned how the street animals live. I learned what difficulties street animals have. I learned how to write a sensor code in Arduino.

All of the students who mentioned birdhouse design activity in their diaries $(f=24)$ made positive comments. In their statements about this activity, students drew attention to, of frequency, its contribution to using design development processes $(f=15)$, having fun $(f=13)$, seeing the importance of teamwork ( $\mathrm{f}=12$ ), and raising awareness of the natural life of birds ( $f=11$ ) and of Sinop Sarıum habitats (nature) $(f=9)$. Some of the statements students made for this activity in their diaries are as follows:

Today, I understood the importance of teamwork, no matter what the subject is. Inoticed the nature in Sarlkum and that it is very important for Sinop.

Today, we had a lot of fun. We learned things about Sarlkum and the birds. We tried to make it using natural sources, but the result was not as expected due to some problems we had in teamwork.

Twenty-two of the students who mentioned Moving Problem for Transport Companies - Crane Design activity in their diaries reported positive comments. When making positive statements, students emphasized using design development processes $(f=9)$, having the chance for creative thinking ( $f=$ 6), having support in improving their skills in the field of coding $(f=5)$, feeling motivated ( $f=5$ ) when addressing a problem of the daily life, having increased interest in engineering ( $\mathrm{f}=$ $2)$, having fun ( $\mathrm{f}=2$ ), and having the chance to do teamwork $(\mathrm{f}=2)$. Some opinions of the students are as follows:

When designing crane, we practiced original, out of the box thinking and cooperation. Also, it was fine to do directional coding; we improved our skill to write codes.
My knowledge of designing robots and writing codes is increasing and getting more fun every day. I feel very good here, and I think I get a better knowledge here. I wish tomorrow were not the end.

Almost all of the students ( $f=23$ ) who included the socioscientific subjects and digital narration: Nuclear power plants activity in their diaries made positive comments, whereas one student made a negative one. The issues mostly pointed at in the comments of students are as follows: Improving their knowledge of socioscientific subjects $(\mathrm{f}=13)$ and contribution to the development of skills such as reasoning $(f=12)$, decision-making $(\mathrm{f}=8)$, searching $(\mathrm{f}=3)$, and problem-solving $(\mathrm{f}=1)$. Some of the student opinions are as follows:

...Today, we learned things about socioscientific subjects. I have a decision now, thanks to these presentations.

...We had to make a decision about a problem, and I saw that this was very difficult. It seems easy to make a quick decision, but today, I learned that it is important to think and question and to find out which one is important and why...

In general, students commented that the activities practiced and the entire process was fun, they gained awareness of the context to which the subjects were related (nature, visual impairment, socioscientific subjects, etc.), improved their coding, design development, teamwork, reasoning, decisionmaking, empathizing, creative thinking, problem-solving, and investigating skills, and boosted their interests in engineering.

\section{$21^{\text {st }}$ Century Skills}

In this study's STEM education program, data were collected using student's diaries and field notes to reach findings of what contributions were made to which $21^{\text {st }}$ century skills of the students. Researchers kept the field notes based on their observations in each of the activities. Field notes of each activity were analyzed one by one to put forward detailed findings.

The activity named traffic lights design for the visually impaired was aimed at raising students' awareness of the lives of visually impaired people and asked them to find a solution for one of the problems these people are faced with crossing the street. It was observed that this process required the students to make active use of the creative thinking processes. The activity included a personal solution finding a stage in which students were asked to generate as many different solutions to the problem as possible. In this stage, students concentrated on finding more than one solution. All stages to include debating solutions among group members, deciding on the best one, and putting the design into practice were observed to be contributing to the cooperation and teamwork skills. Since the entire process was based on the problem-solving/design development process of engineering in which students were expected to work as an engineer, the process could contribute to problem-solving skills.

In the activity titled Water Bowl for Street Animals, it was observed that the problem case, which was in the context of the students, was able to draw their attention. All of the students 
were affected by the problem and highlighted the importance of addressing this issue it to meet the needs of animals, particularly in the summer months. As a result, the social responsibility skills of students developed during the activity. Furthermore, this activity, again based on the design process of engineers, could be considered as suitable for developing problem-solving skills. It was observed that in doing this design work, students generally concentrated on similar solutions (water bowl with tank and sensor). This may be the consequence of the nature of the problem. This activity was also aimed at developing the cooperation and teamwork skills of the students.

Birdhouse design activity was carried out in the Natural Park in Sinop Sarıkum. Students were given information about the ecosystem in Sarikum, the region being on the migration routes of birds, and about the characteristics of some of the bird species living in the region, including their anatomy and feeding styles, and they were asked to design a bird nest using natural materials. It was observed that students had difficulty in working in cooperation for this activity. After having problems in working cooperatively for the stages such as collecting natural materials, planning the design dimensions, and finding original solutions, the groups noted in their comments about the activity that they recognized the importance of teamwork. It was observed that some groups were able to actively manage problem-solving processes during this activity.

Socioscientific subjects and digital narration: Nuclear power plants was the activity during which students were faced with the problem case related to the socioscientific subject of nuclear power plants planned and designed to be set in Sinop. Since the problem was a real-life situation for the students, which they frequently heard about in their own daily life, students were highly motivated during the activity. In parts of the activity including both group and class discussions, they engaged and were actively involved in practices for developing their reasoning, discussing, critical thinking, and searchinginvestigating skills. In addition, since they had to work on their decision-making skills for the subject of nuclear power plants, the process was believed to have improved this skill as well. The activity also required the students to do digital narrating for the arguments that they put forward during the reasoning and decision-making processes. This process was believed to be the one that will improve the student's skills of using the technology interactively.

In the activity named moving problem for transport companies: Crane design students were presented with a problem suitable for their context and asked to find as many solutions as possible. In this activity as well, students were first expected to personally find more than one solution, all being original. It was observed that this process improved student's skills in creative thinking and problem-solving.

Findings obtained from field notes reveal that the activity may improve the $21^{\text {st }}$ century skills of the students including cooperation and teamwork, problem-solving, creative thinking, social responsibility, reasoning, critical thinking, searching- investigating, and using technology interactively.

Student's assessments noted down in the diaries at the end of each day also provided evidence of the $21^{\text {st }}$ century skills they believe to have personally developed. It was found that students mentioned in their diary comment that they gained awareness of the context of the subjects, and therefore, they improved their social responsibility skills in relation to nature, visual impairment, and socioscientific subjects. Students commented that the activities contributed to their personal development in the field of "coding," which indicates the development of the skill of "using technology interactively." Student's comments on having gained awareness of the importance of teamwork prove that the activities supported the "cooperation and teamwork" skills. Students also stated in their assessments that the activities contributed to the development of the $21^{\text {st }}$ century skills including reasoning, decision-making, creative thinking, and problem-solving.

\section{DISCUSSION AND CONCLUSIONS}

The efforts for making STEM education widespread in many countries by way of national education reforms have given the out-of-school learning environments some of the responsibility of making sure that students experience STEM education (Feder and Jolly, 2017). Therefore, international literature suggests doing activities based on an integration of STEM disciplines in informal environments such as STEM centers, science centers, museums, botanic gardens, or by means of planned camp programs (NRC, 2012; 2015; STEM Education Coalition, 2016). Out-of-school programs that contribute to the long-term, intermediate, and short-term goals of STEM education have three design features in common: They are engaging, responsive, and make connections across learning experiences (NRC, 2015).

It was identified in this study that students attending outof-school STEM education had an increased awareness of building a career in the fields of science, engineering, and mathematics. An increase was observed in the field of technology, though not statistically significant. It was found that students participating in this study had above average career awareness scores in the fields of STEM before attending the program. The pre-test scores of students in science and technology were higher than the averages in engineering and mathematics. The fact that this study's students made voluntary applications to participate in STEM activities indicates that these students may already have a strong awareness of careers in STEM fields. Career awareness scores for both science and technology disciplines increased in the post-test measurements, but this increase was less than that in the other disciplines. This may be the reason why the increase in technology discipline was not statistically significant because the increase in career awareness in science and technology disciplines was similar, and the statistical significance level in science discipline was close to the upper limit (Table 1). The difference between the pre- and post-test scores in engineering and mathematics was found to be significant. It would appear that the STEM- 
centered activities implemented were influential in developing these students' awareness of career in the STEM disciplines.

Participants' perception of the fields of STEM and the general perception of building a career in STEM fields of study were found to have increased after their participation in the outof-school STEM education program. Students' perception before attending the program was at average levels. This may be a result of the fact that the project was based on voluntary participation and was, therefore, attended by students who have positive perceptions of these fields.

The results of this research highlighting the positive effects of out-of-school STEM activities on students' perception and awareness of career in STEM fields of study are similar to the research studies by Şahin et al. (2014) and Baran et al. (2016). Şahin et al. (2014) and Baran et al. (2016) reported that students attending out-of-school STEM activities think that these activities encouraged them to build a career in these fields in the future. However, unlike the research previously mentioned this study's research also yielded experimental findings related to the pre- and post-application perception, and career awareness of students was not limited to assessments by students and was, on the contrary, based on a holistic method. Dubetz and Wilson (2013) identified that out-of-school STEM activities increase the interest of female students in secondary schools in STEM. Afterschool Alliance (2013) concluded that the experts who gave support to and carried out the out-of-school STEM programs believed that such programs enhanced the interest of youth in STEM fields, raised awareness of career in these fields, boosted the curiosity for STEM fields, and helped notice the importance of STEM disciplines for the society. On the other hand, in a study performed with university students having education in STEM fields, Dabney et al. (2012) concluded that the interest students had in developing their career in STEM fields boosted by their attendance to scientific activities out of school during their education. Similarly, Nazier's (1993) interviewed professionals working in the fields of science and engineering on what influenced their decision of having a career in these fields. Nazier found that these professionals were encouraged to build a career in these fields after having been involved in some out-of-school applications in the fields of science and mathematics (such as playing games with chemistry kits, hobbies related to mathematics and science, and collecting fossils). All these researches highlight that out-of-school learning environments increase the interest in and the career awareness of the STEM fields of study.

This study's out-of-school STEM program lasted 8 days in which the students addressed five different problems in an interdisciplinary context. It was identified that the out-ofschool STEM activities centered on problem-based learning and engineering design process affected the perception and awareness of students. It was confirmed that students had fun during the activities and generally during the entire process and made positive comments. This result supports the research indicating that children have positive opinions about informal learning environments (Kırıkkaya et al., 2010; Cavaş, 2011). It was also concluded that students think that they have gained awareness about the context the subjects are related to nature, visual impairment, and socioscientific subjects and developed their skills such as coding, design development, teamwork, reasoning, decision-making, empathizing, creative thinking, problem-solving, and researching.

Findings obtained from field notes reveal that the activity may improve the $21^{\text {st }}$ century skills of the students including cooperation and teamwork, problem-solving, creative thinking, social responsibility, reasoning, critical thinking, searchinginvestigating, and using technology interactively. Student's assessments noted down in the diaries at the end of each day also provided evidence of the several $21^{\text {st }}$ century skills of the students. Students mentioned in their diaries that they had improved their skills of social responsibility, interactive use of technology, cooperation and teamwork, reasoning, decisionmaking, creative thinking, and problem-solving. These results of the research support the results of various researches in literature (Baran et al., 2016; Bicer et al., 2015; Sullivan, 2008; Şahin et al., 2014). Sullivan (2008) planned a summer camp of robotic courses for secondary school students and found that the camp improved the systematic thinking skills of the students. Şahin et al. (2014) suggested that afterschool STEM activities were potential contributors to the development of the $21^{\text {st }}$ century skills of students as well as encouraging them for cooperative learning and questioning. Bicer et al. (2015) concluded that summer camps involving project-based learning helped enhance the vocabulary of secondary school students in the fields of mathematics and science.

In consideration of all findings, the research results indicate that STEM education program designed as an out-of-school program improved students' interest in and career awareness of the STEM fields of study. Based on both student comments and field notes of the observing researchers, it was concluded that the program helped to improve various $21^{\text {st }}$ century skills of the students. Students stated positive opinions as well about the out-of-school STEM education program.

In line with the results obtained in the research, this study recommends that out-of-school STEM programs be designed as a short period that includes intensive content to increase students' interest in and career awareness of STEM fields of study. In this study, it was investigated with the observation of researchers, field notes, and student perceptions that contributed to the $21^{\text {st }}$ century skills. Experimental findings based on pre- and post-test measurement may be obtained to investigate the degree to which out-of-school STEM education programs contribute to the $21^{\text {st }}$ century skills (such as decisionmaking and creativity) of the students.

\section{REFERENCES}

Afterschool Alliance. (2013). Defining Youth Outcomes for STEM Learning in Afterschool. Washington, DC. Available from: http://www. 
afterschoolalliance. org/STEM_Outcomes_2013.pdf. [Last retrieved on 2018 Jun 20].

American Association of Colleges and Universities (AACU). (2007). College Learning for the New Global Century. Washington, DC: American Association of Colleges and Universities. Available from: https://www. aacu.org/sites/default/files/files/LEAP/GlobalCentury_final.pdf. [Last retrieved on $2017 \mathrm{Feb}$ 05].

Aydeniz, M., \& Bilican, K. (2017). STEM eğitiminde global gelişmeler ve Türkiye için çıkarımlar [Global developments in STEM education and implications for Turkey]. $3^{\text {rd }}$ ed. In: Çepni, S., (Ed.), Kuramdan Uygulamaya STEM+A+E Egitimi [STEM Education from Theory to Practice]. Turkey, Ankara: PegemA Press. pp. 69-190.

Baran, E., Bilici, S.C., Mesutoglu, C., \& Ocak, C. (2016). Moving STEM beyond schools: Students' perceptions about an out-of-school STEM education program. International Journal of Education in Mathematics, Science and Technology, 4(1), 9-19.

Bicer, A., Beodeker, P., Capraro, R.M., \& Capraro, M.M. (2015). The effects of STEM PBL on students' mathematical and scientific vocabulary knowledge. International Journal of Contemporary Educational Research, 2(2), 69-75.

Brunsell, E. (2012). The engineering design process. In: Brunsell, E., (Ed.), Integrating Engineering + Science in Your Classroom. Arlington, Virginia: National Science Teacher Association Press. pp. 3-7.

Cavaş, B. (2011). Outdoor education in natural life park: An experience from Turkey. Science Education International, 22(2), 152-160.

Christensen, R., \& Knezek, G. (2017). Relationship of middle school student STEM interest to career intent. Journal of Education in Science, Environment and Health, 3(1), 1-13.

Creswell, J.W. (2012). Educational Research: Planning, Conducting, and Evaluating Quantitative and Qualitative Research. $4^{\text {th }}$ ed. Boston: Pearson.

Dabney, K.J., Tai, R.H., Almarode, J.T., MillerFriedmann, J.L., Sonnert, G., Sadler, P.M., \& Hazari, Z. (2012). Out-of-school time science activities and their association with career interest in STEM. International Journal of Science Education, Part B, 2(1), 63-79.

Dubetz, T., \& Wilson, J.A. (2013). Girls in engineering, mathematics and science, GEMS: A science outreach program for middle-school female students. Journal of STEM Education, 14(3), 41-47.

Duch, B.J., Groh, S.E., \& Allen, D.E. (2001). Why problem-based learning? A case study of institutional change in undergraduate education. In: Duch, B., Groh, S., \& Allen D., (Eds.), The Power of the Problem Based Learning. Sterling, VA: Stylus. pp. 3-12.

English, L.D. (2016). STEM education K-12: Perspectives on integration. International Journal of STEM Education, 3(3), 2-8.

Feder, M.A., \& Jolly, E. (2017). What do we Know About Stem in Out-ofSchool Setings? A National Research Council Report. STEM Ready America.

Fllis, A.K., \& Fouts, J.T. (2001). Interdisciplinary curriculum: The research base: The decision to approach music curriculum from an interdisciplinary perspective should include a consideration of all the possible benefits and drawbacks. Music Educators Journal, 87(5), 2268.

Grolnick, W.S., Farkas, M.S., Sohmer, R., Michaels, J., \& Valsiner, J. (2007). Facilitating motivation in young adolescents: Effects of an after-school program. Journal of Applied Developmental Psychology, 28, 332-344.

Gülhan, F., \& Şahin, F. (2016). The effects of science-technologyengineering-math (STEM) integration on $5^{\text {th }}$ grade students' perceptions and attitudes towards these areas. International Journal of Human Sciences, 13(1), 602-620.

Hung, W. (2009). The 9-step problem design process for problem based learning: Application of the 3C3R model. Educational Research Review, 4(2), 118-141.

International Society for Technology in Education (ISTE). (2007). The National Educational Technology Standards and Performance Indicators for Students. Eugene, OR: International Society for Technology in Education.

Kier, M.W., Blanchard, M.R., Osborne, J.W., \& Albert, J.L. (2014). The development of the STEM career interest survey (STEM-CIS). Research in Science Education, 44(3), 461-481.

Kırıkkaya, E.B., Bozkurt, E., \& İşeri, Ş., (2011). Effect of TÜBİTAK supported primary school students science summer school on students image of scientist. Mediterranean Journal of Educational Research, 9, 61-75.

Kizılay, E. (2018). Career and employment in STEM fields in Turkey. The Journal of International Social Research, 11(56), 570-574.

Leblebicioğlu, G., Metin, D., Yardımc1, E., \& Berkyürek, İ. (2011). Teaching the nature of science in the nature: A summer science camp. Elementary Education Online, 10(3), 1037-1055.

Lisbon European Council. (2000). Presidency Conclusions. Available from: http://www.europarl.europa.eu/summits/lis1_en.htm. [Last retrieved on $2018 \mathrm{Jul} 17]$

Marshall, C., \& Rossman, G.B. (2006). Designing Qualitative Research. $4^{\text {th }}$ ed. USA: Sage Publications.

Metin, D., \& Leblebicioğlu, G. (2011). How did a science camp affect children's conceptions of science? Asia-Pacific Forum on Science Learning and Teaching, 12(1), 1-29.

Muro, J., \& Kottman, T. (1995). Guidance and Counselling in the Elementary and Middle Schools. Dubuque, IA: Brown and Benchmark.

National Academy of Engineering (NAE) and National Research Council (NRC). (2009). Engineering in K-12 Education Understanding the Status and Improving the Prospects. Washington, DC: National Academies Press.

National Assessment Governing Board (NAGB). (2014). Technology and Engineering Literacy Framework for the 2014 National Assessment of Educational Progress. Available from: https://www.dese.mo.gov/ sites/default/files/asmt-naep-frameworks-2014-technology-frameworkabridged.pdf. [Last retrieved on 2019 Mar 22].

National Research Council (NRC). (2009). Learning Science in Informal Environments: People, Places, and Pursuits. Available from: http:// www.nap.edu/catalog.php?record_id $=12190$. [Last retrieved on 2016 Oct 25].

National Research Council (NRC). (2012). A Framework for k-12 Science Education: Practices, Crosscutting Concepts, and Core Ideas. Washington DC: The National Academic Press.

National Research Council (NRC). (2015). Identifying and Supporting Productive STEM Programs in Out-of-School Settings, Committee on Successful Out-of-School Stem Learning, Board on Science Education, Division of Behavioral and Social Sciences and Education. Washington, DC: The National Academies Press.

Nazier, G.L. (1993). Science and engineering professors: Why did they choose science as a career? School Science and Mathematics, 93(6), 321-327.

Next Generations Science Standards (NGGS). (2013). The Next Generation Science Standards-Executive Summary. Available from: http://www. nextgenscience.org/sites/ngss/files/Final\%20Release\%20NGSS\%20 Fron $\mathrm{t} \% 20$ Matter $\% 20-\% 206.17 .13 \% 20$ Update_0.pdf. [Last retrieved on 2017 Aug 15].

Organization for Economic Cooperation and Development (OECD). (2017). OECD Skills Outlook 2017-Skills and Global Value Chains. Available from: http://www.oecd.org/education/skills-beyond-school/oecd-skillsoutlook-2017-9789264273351-en.htm.[Last accessed on 2018 July]

Partnership for $21^{\text {st }}$ Century Skills (P21). (2013). A Report and Mile Guide for $21^{\text {th }}$ Century Skills. Washington DC: Partnership for $21^{\text {st }}$ Century Skills.

President's Council of Advisors on Science and Technology (PCAST) (2010). Prepare and Inspire: K-12 Education in Science, Technology, Engineering, and Math (STEM) for America's Future. Available from: http://www.whitehouse.gov/sites/default/files/microsites/ostp/pcaststemedreport.pdf. [Last retrieved on 2018 Mar 12].

Şahin, A., Ayar, M.C., \& Adıgüzel, T. (2014). STEM related after-school program activities and associated outcomes on student learning. Educational Science: Theory and Practice, 14(1), 309-322.

Shaughnessy, J.J., Zechmeisteri, E.B., \& Zechmeister, J.S. (2006). Research Methods in Psychology. $7^{\text {th }}$ ed. New York: McGraw Hill Higher Education.

Smith, J., \& Karr-Kidwell, P. (2000). The Interdisciplinary Curriculum: A Literary Review and a Manual for Administrators and Teachers. (ED443172) Available from: http://www.ERICdatabase. [Last retrieved on 2013 Jan 02].

STEM Education Coalition. (2016). 2016 Annual Report. Available from: 
http://www.stemedcoalition.org/wp-content/uploads/2016/01/2016Annual-Report-Final.pdf. [Last retrieved on 2018 Apr 25].

Stevens, R., Bransford, J., \& Stevens, A. (2005). The LIFE Center's Lifelong and Life-wide Diagram. Available from: http://www.life-slc.org/ about/citationdetails.html. [Last retrieved on 2013 Jan 12].

Sullivan, F.R. (2008). Robotics and science literacy: Thinking skills, science process skills and systems understanding. Journal of Research in Science Teaching, 45(3), 373-394.

Turkish Industry and Business Association. (2014). Demand and Expectations Research for Labor Force Trained in STEM. Available from: http://www.stemtusiad.org/bilgi merkezi/anket-raporu. [Last retrieved on $2016 \mathrm{Jul} 14]$.

Uitto, A., Juuti, K., Lavonen, J., \& Meisalo, V. (2006). Students' interest in biology and their out-of-school experiences. Journal of Biological Education, 40(3), 124-129.

Ünlü, Z.K., Dokme, I., \& Ünlü, V. (2016). Adaptation of the science, technology, engineering, and mathematics career interest survey (STEM-CIS) into Turkish. Eurasian Journal of Educational Research, 63, 21-36.

Wyss, V.L., Heulskamp, D., \& Siebert, C.J. (2011). Increasing middle school student interest in STEM careers with videos of scientists. International Journal of Environmental and Science, 7(4), 501-522. 